\title{
Sugar Prices, Labor Income, and Poverty in Brazil
}

\author{
Ekaterina Krivonos* \\ Marcelo Olarreaga ${ }^{\dagger}$
}

This paper assesses the impact that a potential liberalization of sugar regimes in OECD countries could have on household labor income and poverty in Brazil. The authors first estimate the extent of price transmission from world markets to 11 Brazilian states to capture the fact that some local markets may be relatively more isolated from changes in world prices. They then simultaneously estimate the impact that changes in domestic sugar prices have on regional wages and employment depending on worker characteristics. Finally, they measure the impact on household income of a 10 percent increase in world sugar prices. Results suggest that workers in the sugar sector and in sugar-producing regions have better employment opportunities and experience larger wage increases. More interestingly, households at the top of the income distribution experience larger income gains due to higher wages, whereas households at the bottom of the distribution experience larger income gains due to movements out of unemployment.

\section{World Bank Policy Research Working Paper 3874, April 2006}

The Policy Research Working Paper Series disseminates the findings of work in progress to encourage the exchange of ideas about development issues. An objective of the series is to get the findings out quickly, even if the presentations are less than fully polished. The papers carry the names of the authors and should be cited accordingly. The findings, interpretations, and conclusions expressed in this paper are entirely those of the authors. They do not necessarily represent the view of the World Bank, its Executive Directors, or the countries they represent. Policy Research Working Papers are available online at http://econ.worldbank.org.

We are grateful to Bruce Gardner, Bernard Hoekman, Don Mitchell, Marcia Moraes, Alessandro Nicita, Guido Porto, Maurice Schiff, Thierry Verdier, Ethan Weisman, and participants at a World Bank seminar for very helpful comments and discussions.

\footnotetext{
* University of Maryland, email: ekrivonos @arec.umd.edu.

† Office of the Chief Economist for Latin America, The World Bank,, Carrera 7, \#7-21, Piso 16, Bogota, Colombia, and DEPR, Long, UK. Tel. (571) 326-3600: Fax: (571) 326-3600, email: molarreaga@worldbank.org.
} 
"Why the hell should I give up what I have if in fact it's not going to be to the benefit of anyone, but a middleman?... The poorest of the poor gets hardly anything, but this is being advertised as a benefit of reform"

Jack Wilkinson, President of the International Federation of Agricultural Producers, Speaking at the World Sugar Conference in Fargo, North Dakota in August 2004 .

\section{Introduction}

Sugar is produced in 121 countries in the world. ${ }^{1}$ It remains one of the most distorted sectors in the world, and only in a handful of countries producers face world prices. In many industrialized countries sugar producers benefit from all sorts of border protection, as well as domestic and export subsidies. There has been significant pressure on OECD countries to liberalize their sugar sector. Some estimates suggest that world prices could increase by as much as 40 percent following the elimination of all trade distorting policies in this sector (Mitchell, 2005), and this could benefit many developing countries which have a natural comparative advantage in the production of sugar. Brazil is likely to be one of the largest beneficiaries from such a reform. ${ }^{2}$ It is the largest producer and exporter of sugar in the world, accounting for 28 percent of world sugar cane production and 25 percent of world sugar

\footnotetext{
${ }^{1}$ Around 60 to 70 percent of world production takes place in tropical countries from sugar cane and 30 to 40 percent in more temperate climates from sugar beet.

${ }^{2}$ Brazil has recently won a WTO dispute that requires the EU to reduce its sugar subsidies. Moreover, the EU has announced a reform that would cut its reference price by around 40 percent. If accompanied by a reduction in border barriers in the EU, this could lead to a significant increase in the world price of sugar. Note, however, that the development implications of the EU reform are not clear as many developing countries (those benefiting from ACP preferences) would lose from EU reforms, as ACP sugar exporters benefit from quota constrained high reference prices when exporting sugar to the EU.
} 
exports.

But who is likely to be the largest winner within Brazil? Some have argued that given the structure of the sugar sector, and the large mechanization it has experienced in recent years, very little of the economic gains will accrue to small farmers and agricultural workers in Brazil. Rather, reforms in the OECD are likely to benefit almost exclusively large multinational firms investing in Brazil. Indeed, since Brazil opened its sugar sector to foreign investment in the late 1980s around 30 European firms established their presence in Brazil, representing about 10 percent of the sector's total output (Moraes, 2004). ${ }^{3}$ Nevertheless, the impact of an increase in sugar prices on the poorest segments of the population can be quite large. The sugar sector accounts for a substantial share of employment among the poor in Brazil. A third of sugar workers in the North and Northeast are illiterate, and almost 60 percent of sugar workers in Brazil have not completed primary school. Moreover, the sugar sector's overall contribution to GDP and employment is around 1 percent and reaches 3 to 4 percent in Pernambuco. General equilibrium effects may lead to relatively large impact on wages and employment in other sectors as well, depending on inter-industry linkages and factor mobility across sectors and industries. Thus, the presence of foreign capital in a relatively concentrated sector does not preclude significant impacts on labor markets, which can significantly contribute to poverty reduction in some regions of Brazil.

\footnotetext{
${ }^{3}$ This includes serveral large groups such as FDA (a joint-venture formed by Brazilian group Cosan, with participation of 47.5 percent, and by French groups Tereos/Union DAS, also with 47.5 percent, and Sucres \& Denrées/Sucden, holding 5 percent); Coinbra/Louis Dreyfus (takeover of two sugar mills Luciania Mill and Cresciumal), Béghin-Say (takeover of Guarani sugar mill) and Glencore Group from Switzlerand.
} 
This paper investigates how changes in the world price of sugar could affect individuals within different segments of the income distribution by focusing on the relationship between sugar prices, wages and employment. Thus, we first estimate the extent of price transmission from world markets to eleven Brazilian states. Some states may be more isolated than others, and our first step is an attempt to capture the heterogeneity in price transmission to different regions. Then, we simultaneously estimate the impact that changes in local sugar prices have on regional wages and employment for workers with different characteristics. Finally, we simulate the impact of a 10 percent increase in world sugar prices on household's labor income. ${ }^{4}$

Empirical results suggest that in the long run price transmission is above 70 percent except for the poor states of Pernambuco and Bahia. Increases in wages associated with higher sugar prices tend to benefit relatively more workers in the sugar sector, but workers in other sectors also benefit, suggesting that there is imperfect intersectoral mobility. ${ }^{5}$ There is also imperfect inter-regional mobility as workers in sugar growing and processing regions experience higher wage changes than workers in other regions.

More interestingly, better educated workers generally experience higher wage increments when sugar prices increase. This may be partly due to the fact that mechanization has made this sector more capital and skilled intensive. ${ }^{6}$ An alternative explanation, which seems to be more consistent

\footnotetext{
${ }^{4} \mathrm{~A} 10$ percent increase in the world price of sugar is at the lower end of the range of estimates provided in the literature (see Mitchell, 2005). To obtain percentage changes in income for other estimates of changes in world price, see footnote 20.

${ }^{5}$ For evidence on this see Pavnick et al. (2004).

${ }^{6}$ Also, higher sugar prices may be taxing downstream sector such as the food industry which may be relatively more intensive on low-skilled labor and therefore the net effect on relative skilled-unskilled labor demand is ambiguous.
} 
with our empirical results, is that an important pool of unemployed unskilled workers puts downward pressure on the wages of poor and unskilled workers. Therefore, their wages are relatively less sensitive to changes in labor demand. This is confirmed by the fact that even though more educated workers experience higher percentage increases in wages, the largest increases in employment were observed for unskilled workers.

Thus, if the wage effects tend to benefit relatively more workers in the top income quintiles, the employment effect benefited relatively more workers belonging to the bottom income quintiles, who are moving out of unemployment. When these two effects are put together, households throughout the income distribution tend to experience similar gains, even though the sources of gain are different.

Assuming a 10 percent increase in world prices, aggregate labor income changes amount to $\$ 5$ billion (or 1.04 percent of GDP). Thus, Brazilian workers are likely to benefit substantially from liberalization of the sugar sector in OECD countries. Our estimates also suggest that around 450 thousand Brazilians will be brought out of poverty following a 10 percent increase in world sugar prices.

The rest of the paper is organized as follows. Section 2 provides background information on the functioning of the sugar sector in Brazil and the characteristics of its labor force. Section 3 discusses the empirical methodology used to estimate the transmission of changes in the world price of sugar into local sugar prices and the impact of local prices on wages and employment. Section 4 presents the empirical results. Section 5 concludes. A data appendix discusses data sources and variable construction. 


\section{Brazil's sugar sector and its labor force}

Brazil is the world's largest sugar producer and exporter. It produces around 28 percent of all sugar cane in the world and exports around 25 percent of the world's total processed raw sugar (FAOSTAT). ${ }^{7}$ One crucial feature of the sugar cane industry is the close relationship between harvesting and processing - the raw cane has to be transported to the mill fast, since the quality of sugar deteriorates rapidly following the cutting of cane. This prompts the mills to be located in the midst of the sugar cane area. There are two main sugar cane producing regions: Center-Southeast and North-Northeast. There are approximately 300 plants processing sugar cane (sugar mills), almost 75 percent of which are in the Center-South. Because of poorer soil quality, the costs of growing sugar cane are higher in the North. Processing costs are also higher in the North than in the Center-South. The state of São Paulo in the Center-South is by far the biggest producer. It accounts for 75-80 percent of sugar cane production and 60-65 percent of sugar production (see Table 1). The North-Northeast (mainly the states of Pernambuco), however, accounts for 70-75 percent of exports (Bollings and Suarez, 2002). Almost 45 percent of all production is consumed domestically. Domestic food manufacturers account for approximately 35-45 percent of the total consumption, the rest being direct consumption.

Prior to sugar sector in the 1990s reforms the Brazilian sugar and alcohol industry was highly regulated, and the policies for sugar and ethanol were interconnected. Sugar mills and distilleries received credit guarantees and

\footnotetext{
${ }^{7} \mathrm{~A}$ bit more than half of Brazilian sugar cane is used for the production of ethanol (fuel alcohol). Brazil's interest in ethanol production dates back to the first oil crisis. The ethanol content of gasoline is regulated by decree at around 20 to 24 percent.
} 
subsidized interest rates. Domestic marketing of sugar and alcohol was statecontrolled, with the Institute of Sugar and Alcohol (IAA) acting as a state trading enterprise, setting production quotas and allocating them among the sugar mills and distilleries. Above-quota production was allowed to be exported subject to licensing requirements and export tax. The government fixed domestic prices paid to sugar cane growers, giving higher prices to the growers in the high-cost production areas in the North.

IAA was dissolved in 1990. The reforms of the sugar market focused on disentangling sugar and ethanol policies and releasing the control over the domestic prices of sugar. The export tax on sugar was lowered and eventually eliminated. Production tax was made uniform across regions. In 1998 the state monopoly controlling ethanol distribution was abolished. The main outcomes of deregulation were market-determined sugar and alcohol prices (with domestic sugar prices following world market prices). A new competitive environment was brought by changes in market structure, while the concentration in the sector increased though mergers and acquisitions and inflows of foreign capital (Moraes, 2004).

Four distinct groups involved in sugar production can be identified: sugar mills, independent sugar cane producers, hired agricultural workers and industrial workers. Each is represented by one or more organizations that define the institutional setting of the sugar sector. The earnings of each group, including minimum wages of workers and the price of sugar cane paid to producers, depend on the outcome of annual negotiations between the various entities. The minimum wages negotiated in 2003/2004 were 51 US cents per hour for hired agricultural workers and 56 US cents for mill workers, 
corresponding to $\$ 113$ and $\$ 122$ per month, respectively (Moraes, 2004).

Around 75 percent of sugar cane is grown by the mills, which hire seasonal workers at hourly wages, while the rest belongs to independent producers (Moraes, 2004). In 2002, approximately 765 thousand people were employed in sugar and alcohol production. Of these, around 48 percent were employed in sugar cane production. Only 12 percent were employed in the alcohol producing sector. According to interviews with workers' representatives in the sector, Moraes (2004) estimates that 95 percent of employment is formal. Table 2 shows the distribution of workers by region, age groups and education levels for both sugar cane growing and production of sugar. 40 percent more workers were employed in the Central-South region than in the North. The ratio of employment to production (combining Table 1 and 2) suggests that the Central-South region is 2.5 times more productive than the North region. This is mainly explained by the quality of land in different regions, but also the higher degree of mechanization in the Central-South region. This is also reflected in the significant differences in the level of education of sugar workers across regions. In the Central-South region only 4 percent of workers are illiterate, whereas in the North the proportion is roughly one-third.

The average level of education among workers in the sugar sector (3.7 years) is higher than in the rest of the agricultural sector (2.8 years), but substantially lower than the average for the economy as a whole (6.4 years). The sugar sector has traditionally been relatively intensive in low-skilled labor. Table 3 shows the ratio of high-educated workers (defined as those with more than 8 years of education) to low-educated workers (defined as those with less than 5 years of education) in different sectors in Brazil. The sugar grow- 
ing and processing sectors employ a relatively small share of high-educated workers relative to other sectors -with the exception of other agricultural sectors. Note that sectors that are heavy sugar consumers such as food and beverages industries are relatively intensive in high-educated workers, which suggest that these type of general equilibrium linkages would only reinforce the relatively low-educated intensity of the sugar sector. However, over the last decade the share of high-educated workers in the sugar processing and growing sectors grew drastically relative to the rest of the economy, growing on average 6 times more (see last column of Table 3 ).

This is partly due to the transformation that the sector has undergone over the past decade. Reforms resulted in a transformation of the sector from being primarily family owned to an industry dominated by larger, technologically advanced factories. Sugar cane loading, transport and cultivation is 100 percent mechanized and harvesting is around 35 percent mechanized. ${ }^{8}$ The mechanization has reduced the demand for workers (Guilhoto et al., 2002), especially for those with low skills. The sector has become relatively capital intensive (labor costs representing around 25 percent of value-added for an average of 35 percent in manufacturing).

These changes led to growing demand for high-skilled workers. The Escola Superior de Agricultura "Luiz de Queiroz" (ESALQ), of the University of São Paulo, has graduated three MBA classes, and offers shorter technical courses, which target the sugar sector. The Ribeirao Preto Economics College (FEARP), of the University of São Paulo, has graduated three MBA classes

\footnotetext{
${ }^{8}$ According to Ricci et al (1994), this mechanization was prompted by the sector reforms that created incentives for firms to undertake cost reducing investments and the legislation banning cane burning as a detrashing method.
} 
targeted to employees of two large sugar companies (Crystalserv and Grupo Rezende Barboza). The fact that MBA courses are being targeted to the sugar sector seems to suggest that there is a certain level of sector specific skills that need to be acquired. Thus, one may expect that changes in sugar prices would have a higher impact on wages of skilled workers in the sugar sector if these have relatively more sector specific skills. This will be tested in the empirical section.

\section{Empirical methodology}

In order to evaluate the impact of world sugar prices on household income we proceed in three steps. First, we estimate the extent of price transmission from world sugar prices to local markets. Second, we estimate the impact of local sugar prices on wages and employment in different categories of the labor force. Finally, using these estimates, we simulate for each income quintile the impact of a 10 percent increase in world prices on household income. The three steps are described below.

\subsection{From world to local sugar prices}

The extent of price transmission from world to local markets depends on how well integrated these markets are with the world market. Distance to ports, road infrastructure, access to information all play a role. These characteristics are likely to vary from one region to another affecting the impact that changes in world prices will have on earnings in each region.

First we use an Engle-Granger residual-based tests to determine the long- 
term cointegrating relationship between each of the local prices and the world price. This is done by regressing the price in each state on the world price:

$$
\ln p_{t}^{d}=\alpha+\gamma \ln p_{t}^{w}+\mu_{t}
$$

If in fact a cointegrating relationship between the price pairs exists, the OLS estimator is consistent despite the apparent problem of nonstationarity of the price-time series and the problem of replacing a simultaneous-equation model for all states with a single equation (Greene, 2000). Equation (1) is estimated for each of the states using a Seemingly Unrelated Regression (SUR) to control for any exogenous shock that may be affecting prices in a similar way in all regions. The prices used in the analysis are in log form, which allows us to interpret the coefficients of cointegration as long-term elasticities of the local prices with respect to the world price. We will use these estimates when simulating the impact of a 10 percent increase in world prices on local wages and employment. To establish cointegration, the residuals $\mu_{t}$ are tested for unit root using the Augmented Dickey-Fuller (ADF) procedure. ${ }^{9}$

In addition to estimating the cointegrating vectors we estimate an errorcorrection model to explain the dynamics around the long-term cointegrating relationship. The response of domestic prices to changes in the world price is decomposed into an immediate change following the shift in prices and an

\footnotetext{
${ }^{9}$ The ADF test for a unit root without trend involves estimating the following equation for a time-series variable $y_{t}: \Delta y_{t}=\beta+\lambda y_{t-1}+\sum_{j=1}^{k} \eta_{j} \Delta y_{t-j}+v_{t}$ where $k$ is the number of lags of the first differences used. The null hypothesis is that each of the time series follows a nonstationary process with a unit root, i.e., $\lambda=0$ (which is tested against $\lambda<0$ ). If the null of unit root is rejected, we proceed as if the domestic and world price series are cointegrated.
} 
adjustment to the long-term equilibrium in the following period: ${ }^{10}$

$$
\ln p_{t}^{d}-\ln p_{t-1}^{d}=\eta+\delta\left(\ln p_{t}^{w}-\ln p_{t-1}^{w}\right)+\theta\left(\ln p_{t-1}^{d}-\alpha-\gamma \ln p_{t-1}^{w}\right)+\varepsilon_{t}
$$

where $p_{t}^{d}$ is the domestic price in period $t$ and $p_{t}^{w}$ is the corresponding world price; $\delta$ captures the instantaneous response of domestic prices to changes in world prices, and $\theta$ is the error-correction parameter, which captures the speed of adjustment of $p_{t}^{d}$ to its long-run equilibrium $\gamma p_{t}^{w}$. We use the residuals from the Engle-Granger cointegration test $\left(\widehat{\mu}_{t}\right)$ for each state as the error-correction term. Again, SUR is used to estimate 11 equations of type (2): one for each of the states in our sample. Prior to estimation we ensure that the first differences of the price time series used in the error-correction model (1) are stationary using an ADF test.

\subsection{The impact of local sugar prices on wages and em- ployment}

To estimate the impact of local prices on wages and employment in Brazil we use a Heckman sample selection model where we only observe the wages of the respondents that have been employed during the survey period. The wage equation estimates the impact of sugar prices (as well as individual and regional characteristics) on a person's wage. We allow the impact of sugar prices to vary according to individual characteristics including sector of employment and geographical location of the household. Note that even workers in non-sugar sectors in non-sugar producing regions can see their

\footnotetext{
${ }^{10}$ See Baffes and Gardner (2003) for a detailed derivation.
} 
wage change, if labor markets are integrated, or if sugar is a complement or substitute in the production or consumption of other goods. ${ }^{11}$

The Heckman model corrects for the potential selection bias that OLS estimation would produce due to the fact that we only observe the wages of those individuals that were employed. Correction is done by specifying a selection equation that describes the latent variable $z_{i}^{*}$ :

$$
\begin{aligned}
& z_{i}^{*}=\xi^{\prime} x_{i}+\varepsilon_{i} ; \\
& z_{i}=\left\{\begin{array}{rr}
1 & \text { if } z_{i}^{*}>0 \\
0 & \text { otherwise }
\end{array}\right.
\end{aligned}
$$

where $\xi$ is a vector of parameters and $x_{i}$ is a vector of independent variables determining the employment status of individual $i$ (time period subscripts are dropped for simplicity). This can be written as a probit model. The probit equation describes employment as a function of individual and regional characteristics. The variables included in this equation are real price of sugar, number of children below age 15 in the household, age of the worker and age squared, education level, race and gender of the worker, a dummy for urban/rural household location and interaction terms where real price of sugar is interacted with education level and the dummy for being located in a major sugar producing region. The coefficients on sugar prices will allow us to capture the impact that changes in the sugar price have on the employment probabilities of different individuals, the implicit assumption being that all

\footnotetext{
${ }^{11}$ In the case of consumption one would need the complement or substitute good to be a non-traded good so that its price is not exogenously determined by world markets.
} 
individuals deciding to participate in the labor market will be offered a job ${ }^{12}$.

The second equation in the labor market model is the wage regression:

$$
\ln w_{i}=\beta_{0}+\sum_{s} \beta_{s} S_{s, i}+\sum_{c} \beta_{c} C_{c, i}+\beta_{p} \ln p_{s}^{d}+\sum_{k} \beta_{k} K_{k, i} \ln p_{s}^{d}+e_{i}
$$

where $w_{i}$ is the hourly real wage of individual $i, S_{s, i}$ are state variables for individual $i$ (such as whether the region is a major sugar growing region), $C_{c, i}$ are individual characteristics variables for individual $i$ (such as gender, age, education, etc.) and $p_{s}^{d}$ is the real local price of sugar in state $s$ (prices normalized by CPI in each state). The last term (the sum over $k$ ) captures the interaction term between real sugar prices and a subset $K_{k}$ of individual and state characteristics variables.

The wage equation is estimated using the observations for which wage data exist (i.e. observations on individuals that were employed at the time of the survey). The explanatory variables are the same variables as in the selection equation (except the number of children which is likely to determine labor market participation but not wages) with addition of some employment specific variables such as sector dummies (sugar growing, sugar processing, agriculture other than sugar, industry other than sugar and services) and dummies for the type of employment (hired worker, self-employed and employer). Sugar prices are also interacted with these additional variables to capture the heterogeneity of the sugar price impact along these dimensions

\footnotetext{
${ }^{12}$ In a related paper Porto $(2005 \mathrm{~b})$ is able to disentangle whether individuals deciding to participate in the labor market are offered a job. This allow him to distinguish between demand and supply side variables affecting the equilibrium level of employment and unemployment.
} 
(see Porto, 2003, 2005a or 2005b or Nicita 2004a for a similar approach).

The interaction terms that are used in both the selection and wage equations imply that the elasticities of wage and labor market participation with respect to sugar prices vary from one individual to another, according to her level of education, her geographic location, the sector where she works and the type of employment. This proves to be important in estimating the impact of changes in sugar prices on household income at different points of the income distribution.

The Heckman selection model is estimated using maximum likelihood. The estimates from this model allow us not only to calculate how wages would change following a change in the price of sugar, but also to measure the impact that changes in sugar prices may have on the labor market participation of each individual. Thus, we can estimate the impact of changes in local sugar prices on both wages and employment.

In order to correct for possible correlation of the error terms within survey sample strata in each year, we use cluster robust error terms, where the clusters are defined by sample strata/year. All regressions include year and state dummies.

\subsection{Simulating the impact on household's labor in- come}

The third step consists of simulating the impact of a 10 percent increase of sugar world prices on households' labor income. For this task we use the 
estimates from the first and second steps. ${ }^{13}$ The change in sugar prices will affect labor income through two channels: wages and employment. We focus on each of these in turn.

To capture the first effect, let us define the wage elasticity of individual $i$ as $\omega_{i}$. Then using (5)

$$
\omega_{i} \equiv \frac{\partial \ln w_{i}}{\partial \ln p_{s}^{d}}=\beta_{p}+\sum_{k} \beta_{k} K_{k, i}
$$

But we are interested in the elasticity with respect to world prices. Using the estimates in (1) we have that $\partial \ln p_{s}^{d} / \partial \ln p^{w}=\gamma_{s}$. Thus, the percent change in real hourly wages experienced by individual $i$ following a 10 percent increase in the world price of sugar is given by:

$$
\widehat{\omega}_{i}=0.10 \gamma_{s} \omega_{i}
$$

Denote $\bar{w}_{i}$ the predicted real hourly wage of person $i$ before the sugar price change, conditional on her being employed. Then her predicted real hourly wage after the 10 percent sugar price increase is $\bar{w}_{i}^{\prime}=\left(1+\widehat{\omega}_{i}\right) \bar{w}_{i}$.

Thus, for those currently working, the change in the expected real monthly

\footnotetext{
${ }^{13}$ Note that to have the full impact on household's real income we would need to have information on the share of sugar in the consumption basket of each household, as well as the sensitivity of sugar demand to changes in prices (see e.g., Nicita, 2004b). This information is not available from labor surveys, so we focus only on the impact on labor income. Because sugar prices are increasing this means that at least in this sense our calculations overestimate the impact on real income. However a back of the envelope calculation suggest that overestimation is not a serious problem. The weight that the Brazilian statistical office (Instituto Brasileiro de Geografia e Estatística - IBGE) puts on sugar in its consumer price index is 0.8 . So on average sugar accounts for 0.8 percent of household expenditure and therefore an upper bound for the real income loss associated with a 10 percent increase in sugar prices (i.e. abstracting from any substitution possibility and frictions in price transmission) is around 0.08 percent.
} 
wage is given by:

$$
\Delta^{w} y_{i}=\left(\bar{\pi}_{i}^{\prime} \bar{w}_{i}^{\prime}-\bar{\pi}_{i} \bar{w}_{i}\right) \ell_{i}
$$

where $\ell_{i}$ is the number of hours worked by individual $i$ per month and $\pi_{i}$ and $\bar{\pi}_{i}^{\prime}$ are the predicted probabilities of individual $i$ of being employed before and after the sugar price change, respectively. The predicted probabilities were obtained using the estimates from the Heckman model.

Next we calculate the change in income for individuals that were not working prior to the price change. Note that wages are not the only source of household income. Labor income accounted for 78 percent of all income, but households also received dividends, interest, pensions, unemployment benefits and safety net transfers, which together accounted for the remaining 22 percent. Around $18 \%$ of the individuals not employed at the time the survey was conducted received some form of social benefits. Since the probability of being employed increases for most people as the sugar price rises, we assume that the person may choose to work following an increase in the price, but only if her expected wage exceeds the benefits currently received (unemployment benefits, social assistance, disability assistance, old age assistance, etc). We assume that a person forfeits those transfers if she becomes employed. We also assume that anyone entering the labor force works full-time and gets her average expected wage across sectors. Other types of income, such as interest and dividends, are assumed to be unaffected by sugar prices. The change in expected income of individual $j$ due to the change in the probability of being employed is then given by the difference between the predicted income after the price change net of predicted income prior to sugar price 
liberalization:

$$
\Delta^{e} y_{j}=\left(\bar{\pi}_{j}^{\prime} \bar{w}_{j}^{\prime} \ell+\left(1-\bar{\pi}_{j}^{\prime}\right) U_{j}\right)-\left(\bar{\pi}_{j} \bar{w}_{j} \ell+\left(1-\bar{\pi}_{j}\right) U_{j}\right)
$$

where $\ell$ is approximately 172 hours worked per month (corresponding to 40 hours per week), $U_{j}$ is social benefits received by individual $j$ and $\pi_{j}$ and $\bar{\pi}_{j}^{\prime}$ are the predicted probabilities of person $j$ being employed before and after the sugar price change, respectively (conditional on her being employed and averaged across sectors $)^{14}$. Note that in most cases $U_{j}$ is zero.

The total expected change in households' income is obtained by summing up the change in labor income of all household members that were employed, as described by (8), and all members that were not employed, as described by $(9) .{ }^{15}$

\section{Empirical results}

We start by presenting the results of price transmission estimates. We then turn to the estimates of the wage and employment elasticities with respect to sugar prices and we conclude this section with the simulation results.

\subsection{Price transmission results}

We first check which of the Brazilian states in our sample are cointegrated with the world market and estimate the parameters of the long-term rela-

\footnotetext{
${ }^{14}$ We tried different specifications, giving more or less weight to wages in the sugar sector, but this did not change our qualitative results.

${ }^{15}$ For calculation of percentage change in income we use the predicted initial total income from all sources as the denominator.
} 
tionship between the local and the world prices of sugar. The stationarity of the price times series used in the model is tested and the appropriate ADF statistics are reported in Table 4. For neither London Daily Price nor the Brazilian prices the ADF test rejects the null hypothesis that the prices follow a unit root process. ${ }^{16}$ However, redoing the test in terms of first differences leads to rejection of the unit root hypothesis at 1 percent level for all price time series. Thus, price differentials can be used in the error-correction model.

We then test for a long-term cointegration between the local and the international prices as described by equation 1. The test statistics, also reported in Table 4, imply that for all states except Pernambuco and Para, we should reject the hypothesis of no cointegration between the local and the world prices at the 1 percent significance level. In Pernambuco we reject the hypothesis at 10 percent. In Para, the ADF statistic for the residual is very close to the 10 percent critical value, so we estimate an error-correction model for Para along with the other states, although we can not conclude that the prices in that region are closely integrated with world prices.

The results of error-correction estimation for the 11 states are reported in Table 5. The long-term cointegration coefficient $(\gamma)$ was obtained from equation (1) and the coefficients of short-term transmission $(\delta)$ and adjustment $(\theta)$ were estimated using equation (2). In São Paulo, where by far most sugar is produced and traded, a 1 percent increase in the world price of sugar leads to 1 percent increase in the local price in the long run (the elasticity is 1.01). ${ }^{17}$ Perfect transmission was also found in Goiás and Minas Gerais,

\footnotetext{
${ }^{16} \mathrm{ADF}$ tests with and without trends give similar results.

${ }^{17}$ See Mundlak and Larson (1992) for similar estimates of agricultural price transmission
} 
which could be explained by the proximity of these states to São Paulo. In other states transmission varies from 0.75 in Pernambuco and Bahia to 0.94 in Rio de Janeiro. Only in few states an immediate adjustment in prices takes place - in Distrito Federal, Goiás and Ceara immediate adjustment is around 0.25 percent and is significant at the 10 percent level. In the other states adjustment begins after the first period (the first month), as reflected by the parameters on the error-correction term.

The estimated coefficients can be used to calculate the adjustment in local prices $n$ periods/months after a one-time change in the world price. With a 1 percent change in the world market price occurring at time $t=0$, the initial percentage change in the local price is given by $\delta$. In the following period the error-correction component $\theta$ is added; $n$ periods after the change in the world price has occurred the domestic prices change by a percentage $m_{n}:$

$$
m_{n}=\gamma-(\gamma-\delta)(1+\theta)^{n}
$$

Table 5 shows the adjustment after 3 months, 6 months and 1 year. In most states, a 1 percent increment in the world price would only increase the local prices by 0.4-0.6 percent after 3 months. However, after a year has passed, the prices in most states become close to their new long-term equilibrium: on average 92 percent of the adjustment occurs within the first year. Given the relatively rapid adjustment, below we use the estimated longterm elasticity of local prices with respect to world prices $(\gamma)$ to evaluate the impact of the change in the international price of sugar on labor income.

across countries and goods. 


\subsection{Wages and employment results}

The results of the maximum-likelihood estimation of the Heckman model are presented in Table 6. The first part contains the coefficients of the wage equation and the second part contains the results of the sample selection equation that determines whether or not the person was employed. The standard errors are adjusted for clustering, where the clusters are sample strata/years. Real sugar prices appear to have significant positive effect on both wages and the probability of holding a paid job. Moreover, these effects depend on certain personal characteristics, i.e. wage elasticity of sugar prices varies across various demographic groups, depending on the level of education, among other things.

Both wages and employment are increasing and concave in age and are positively correlated with education, being a male and living in an urban area. Having young children affects labor market participation negatively. Whites earn higher wages than non-whites, but non-whites participate more actively in the labor force. Wages in sugar processing are substantially higher than in all other sectors, while wages in agriculture other than sugar growing are lowest.

More interestingly, the impact of a change in sugar prices on wages is stronger in the sugar growing sector and the sugar processing industry, which signals some sector specificity. Also, living in a sugar-producing region significantly increases both the elasticity of wages with respect to sugar prices and the effect of sugar prices on labor market participation. Sugar prices affect the wages of well-educated people more than those with less education, ${ }^{18}$

\footnotetext{
${ }^{18}$ Because one may argue that there are unobserved time varying shocks which are simul-
} 
however there are greater employment opportunities associated with sugar price increases among people with fewer years of schooling.

To understand how sugar prices affect different demographic groups in Brazil we compute wage elasticities with respect to prices for persons with different characteristics. These elasticities and their standard errors are reported in Table 7 . Clearly, workers in the sugar processing sector gain most from sugar price increase - their wage would increase by approximately 0.4 to 0.5 percent (depending on their level of education), if sugar prices rise by 1 percent ${ }^{19}$. The gains to workers in sugar growing are also quite large: 0.3 to 0.4 percent. The owners of farms, mills and factories do benefit more from the price increase than the hired workers, but only marginally so for the same level of education the elasticity is 0.04 higher for owners than for workers. Other sectors, apart from services, benefit as well and, welleducated workers are affected most. The only category that is expected to lose slightly (-0.03 percent) from a 10 percent increase in sugar prices is the poorly-educated service workers (such as domestic workers) outside of the main sugar producing areas.

taneously affecting sugar prices and returns to education, we run a similar specification, introducing an interactive term between education and a time trend, but dropping year dummies to avoid multi-collinearity with the time trend. The coefficient on the interaction of education and sugar prices remains positive and significant and while the point estimate is a bit lower (0.009), it is not statistically different from the one reported in Table 6 .

${ }^{19}$ See Pavnick et al. (2004) for evidence of imperfect intersectoral mobility in Brazil's labor markets. 


\subsection{Simulating a 10 percent increase in sugar prices}

First, we provide an estimate of how a 10 percent increase in the world price of sugar would affect wages of those currently employed. ${ }^{20}$ We use the actual survey data to calculate the predicted change in wages for each person employed and aggregate the results for various groups. The results by sector and education level are presented in Table 8. Again, workers in sugar growing and sugar processing stand to gain the most. Even with imperfect transmission (recall that in many states a 10 percent increase in the world price would translate into less than 10 percent increase in the local price) this change would bring a 2 to 4 percent wage increase, depending on the level of education. Workers in the service sector that have low level of education would on average lose 0.5 percent in wages, while well-educated service workers would experience a small gain (0.8 percent).

The first column of Table 9 provides an estimate of the percentage change in household income brought by the change in expected wages of those currently employed (as in Table 8), by income quintile. The average individual in all quintiles benefits from the 10 percent increase in world sugar prices, but the wage increases are larger for individuals in the top income quintile. Conditional on being employed, the average individual in the top two income quintiles experiences an increase in income which is 17 percent higher than the one experienced by the average individual in the bottom two income

${ }^{20}$ Note that all changes in income provided in this section are based on a somewhat arbitrary $10 \%$ increase in the international sugar price. Dividing the percentage income changes reported here by 10 would produce easily interpretable income elasticities with respect to the world price of sugar. In other words, the percentage change in income is linear in the percentage change in world prices and therefore to obtain the percentage change in income after an $x \%$ change in world prices, one can simply multiply the percentage change income reported here by $x / 10$. 
quintiles. This suggests that the first effect (the wage effect) will tend to increase income inequality.

However, the second effect works in the opposite direction. Conditional on being unemployed the change in expected income after a 10 percent increase in the world price is higher at the bottom of the income distribution, as shown in the second column of Table 9. The average unemployed individual in the bottom two income quintiles sees an increase in expected income which is 22 percent higher than the increase in income experienced by the average unemployed individual in the top two income quintiles. This result is not surprising, since it is among the poor that one would find most unemployment, and if one or more household members get a paid job it would translate into a substantial increase in household income among the poor.

The unconditional changes in expected income are given in the third column of Table 9 and incorporate both the changes in wages and the changes in the probability of being employed for all individuals (those currently employed and those currently unemployed). The effects of the two channels described above (wage and employment) are such, that the total gain is almost perfectly homogeneous across quintiles, with an average increase of 1.04 percent. This is equivalent to US\$5 billion in 2002. This is larger than any previous estimate of how much the Brazilian economy would win overall from an increase in sugar prices, which implies that a significant share of the gains should be attributed to workers in the sugar sector, as well as workers in other sectors.

What are the effects of a potential sugar price increase on poverty rates in Brazil? To answer this question we adopt a nominal $1 \$$ per day per capita 
poverty line (close to a $2 \$ \mathrm{PPP}$ poverty line) and calculate the predicted number of poor in each state before and after a 10 percent increase in the world price of sugar. This is done as follows. We first calculate the share of the population below the poverty line in each state using their observed income: 23.4 percent of the population fell below the poverty line in 2002 . We then calculate the predicted income for each individual before and after the price change as described in Section 3.3 and calculate the corresponding predicted poverty rates before and after the change. Finally, we recalculate the number of individuals below the poverty line using the predicted change in the poverty rates. The largest change in predicted poverty rates are observed in São Paulo and Parana which experience declines of 3.9 and 2.7 percent, respectively. However on aggregate the impact of 10 percent increase in world prices is smaller: the poverty rate declines from 23.4 to 23.0 or 1.5 percent. This corresponds to around 450 thousand individuals raising their income above the poverty line.

\section{Concluding remarks}

It has been sometimes argued that most of the gains from a liberalization of sugar policies in OECD countries will mainly benefit rich owners of sugar mills in Brazil - the largest sugar exporter in the world. This paper focuses on the impact that liberalization of sugar policies in the OECD, and the consequent increase in world prices, would have on Brazilian workers through general equilibrium changes in wages and employment. By focusing on labor

income gains we can assess the extent to which the liberalization of sugar 
policies in the OECD is likely to affect the poorest segments of the population in Brazil.

To assess the implications of a 10 percent increase in world sugar prices (which is a conservative estimate of the effect that the elimination of OECD sugar policies would have on world prices) we first estimate the extent of sugar price transmission from world markets to 11 different Brazilian states. We found that domestic markets are closely connected with international markets; in the long run almost 90 percent of world price changes get transmitted to Brazilian domestic prices. The price transmission also occurs relatively fast as on average 92 percent of the adjustment occurs within the first year.

We then estimate the impact that changes in domestic sugar prices have on wages and the probabilities of being employed. We allow these elasticities to vary according to individual and regional characteristics. Workers in the sugar sector experience larger increases in wages than workers in other sectors, signalling some sector specificity. Similarly, workers in sugar producing regions experience much larger increases in wages and the unemployed in sugar producing regions are much more likely to find a job when sugar prices rise, which indicates some geographic frictions on labor mobility. We also found that highly educated workers are likely to experience larger income gains due to wage increases, but individuals with low levels of education tend to benefit relatively more from increases in employment. A potential explanation for this is that there is a larger pool of unemployed low-educated workers which puts downward pressure on the wages of these workers, in spite of a relatively larger demand increase for low-educated workers. Once we aggregate the wage and employment effects the income gains are quite 
homogenous across income quintiles. The average elasticity of labor income with respect to sugar prices is 0.1 which indicates that a 10 percent increase in sugar prices will lead to an average increase in the income of Brazilian workers of about 1 percent or US $\$ 5$ billion. This would lead to a 1.5 percent decline in the poverty rate.

\section{References}

[1] Baffes, John and Bruce Gardner, 2003. The transmission of world commodity prices to domestic markets under policy reforms in developing countries. Policy Reform 6(3), 159-180.

[2] Bolling, Christine and Nydia R. Suarez, 2002. The Brazilian Sugar Industry: Recent Developments. USDA-ERS Briefings.

[3] Guilhoto, J., A, Barros, M. Marjottoa-Maistro, and M. Istake. Mechanization process of the sugar cane harvest and its direct and indirect impact over the employment in Brazil and in its 5 macro regions. Texto de Seminários, IPEUSP, N. 09/2002, 09/05/2002.

[4] Greene, William, 2002. Econometric Analysis. Mac Millan Publishing Company.

[5] Krivonos, Ekaterina, 2004. The impact of coffee market reforms on producer prices and price transmission. Policy Research Working Paper \#3358. The World Bank. 
[6] Moraes, Marcia, 2004. Analysis of the labor market of the Brazilian sugar alcohol sector. Mimeo. University of São Paolo.

[7] Mitchell, Donald, 2005. Sugar policies: an opportunity for change. in A. Aksoy and J. Beghin, eds., Global Agricultural Trade and Developing Countries. The World Bank.

[8] Mundlak, Yair and Donald Larson, 2002. On the transmission of world agricultural prices. World Bank Economic Review 6(3), 399-422.

[9] Pavcnik, Nina, Andreas Blom, Pinelopi Goldberg and Norbert Schady, 2004. Trade liberalization and industry wage structure: evidence from Brazil. World Bank Economic Review 18(3), 319-320.

[10] Porto, Guido, 2003. Using survey data to assess the distributional effects of trade policy. Policy Research Working Paper \#3137. The World Bank

[11] Porto, Guido, 2005a. Informal export barriers and poverty. Journal of International Economics 66(2), 447-470.

[12] Porto, Guido, 2005b. Agricultural exports, wages and unemployment. Mimeo. The World Bank.

[13] Nicita, Alessandro, 2004a. Who benefited from trade liberalization in Mexico? Measuring the effects on household welfare. Policy Research Working paper \#3265. The World Bank.

[14] Nicita, Alessandro, 2004b. Efficiency and equity of a marginal tax reform: income, quality and price elasticities. Policy Research Working Paper \#3266. 
[15] Ricci, R, F. Alves, and J. NOVAES, Mercado de Trabalho do Setor Sucroalcooleiro no Brasil. Brasília: IPEA, 1994. 176p. Estudos de Política Agrícola. Documentos de Trabalho, 15. Projeto PNUD/BRA/91/014.

[16] Vian, C, 2003. Agroindustria canavieira. Estratégias competitivas e moderniza cão. Campinas, São Paolo: Editora Atomo, 2003. 


\section{Data Appendix}

The main source of data for this study is Pesquisa Nacional Por Amostra de Domicilios (PNAD), which are labor market surveys managed by the Brazilian statistical agency IBGE. Surveys have been conducted every year since 1976 with a few exceptions (1980, 1991, 1994 and 2000). PNAD contains extensive information on the wages and other sources of income for each person in the selected household. The survey does not distinguish between formal and informal employment. Sector categories used in replies are highly disaggregated, which allows us to single out workers in the sugar growing sector as well as workers in the sugar processing industry. The data are repeated cross section (samples are redrawn every year for each survey). For this exercise we use the surveys from 1990 to 2002 .

Wages used in the regressions are real hourly wages and prices are real prices of sugar by state. Consumer price indices that were used to convert the variables into real terms were taken from Indice de Precos ao Consumidor Amplo (IPCA) collected by IBGE. The data are available for 11 major cities: Goiânia, Belém, Fortaleza, Recife, Salvador, Belo Horizonte, Rio de Janeiro, São Paulo, Curitiba, Porto Alegre and Brasília). The city level data were used to calculate real wages, real income and real sugar prices for 10 states, respectively: Goiás, Para, Ceara, Pernambuco, Bahia, Minas Gerais, Rio de Janeiro, São Paulo, Parana, Rio Grande do Sul, plus distrito federal. The world price used in the cointegration analysis are the monthly London Daily Price of refined sugar, contract No. 5 fob. The local sugar prices used in regressions are consumer prices, since the existing data for producer prices do not vary by state. 1990-2002 state-level consumer prices were con- 
structed using two sets of data: monthly changes in sugar prices reported in IPCA and the 1996 average sugar prices from household budget surveys (Pesquisa de Or camentos Familiares), also reported by IBGE. Since sugar prices could only be constructed for these 11 states, PNAD observations from other states were dropped, resulting in approximately a 25 percent reduction in the number of observations.

There are two types of sugar most commonly consumed in Brazil: refined sugar and crystal (direct mill white sugar). Crystal is usually cheaper and inferior in quality to refined sugar. For 5 states for which only the prices of crystal sugar are available from the budget surveys (Distrito Federal, Goiás, Pernambuco, Bahia and Minas Gerais) we converted crystal prices into refined prices by using the average ratio of refined to crystal prices in Brazil. Note that the ratio varies over years. 
Table 1: Sugar production in Brazil by State, 1990-2002 ${ }^{a}$ (million tons)

\begin{tabular}{lrrrrrrr}
\hline State/Harvest & $90 / 91$ & $92 / 93$ & $94 / 95$ & $96 / 97$ & $98 / 99$ & $00 / 01$ & $02 / 03$ \\
\hline Para & 0 & 0 & 0 & 0 & 0.01 & 0.01 & 0 \\
Ceara & 0.04 & 0.02 & 0.01 & 0.02 & 0.01 & 0.01 & 0.01 \\
Pernambuco & 1.19 & 1.31 & 1.31 & 1.22 & 1.05 & 1.1 & 1.23 \\
Alagoas & 1.23 & 1.44 & 1.57 & 1.51 & 1.31 & 2.06 & 1.99 \\
Other North & 0.4 & 0.36 & 0.32 & 0.43 & 0.4 & 0.43 & 0.56 \\
\hline North & 2.86 & 3.13 & 3.21 & 3.18 & 2.78 & 3.61 & 3.79 \\
\hline Minas Gerais & 0.41 & 0.37 & 0.45 & 0.49 & 0.63 & 0.62 & 1.09 \\
Rio de Janeiro & 0.28 & 0.32 & 0.39 & 0.42 & 0.37 & 0.31 & 0.31 \\
São Paulo & 3.47 & 5 & 6.68 & 7.93 & 11.79 & 9.68 & 14.35 \\
Parana & 0.22 & 0.23 & 0.43 & 0.78 & 1.24 & 0.99 & 1.47 \\
Rio Grande do Sul & 0 & 0 & 0 & 0 & 0 & 0 & 0 \\
Goias & 0.04 & 0.11 & 0.2 & 0.31 & 0.34 & 0.4 & 0.58 \\
Other Central-South & 0.09 & 0.16 & 0.34 & 0.54 & 0.79 & 0.64 & 0.98 \\
\hline Central \& South & 4.51 & 6.19 & 8.49 & 10.47 & 15.16 & 12.64 & 18.78 \\
\hline Brazil & 7.37 & 9.32 & 11.7 & 13.66 & 17.94 & 16.25 & 22.57
\end{tabular}

${ }^{a}$ Source: Moraes, 2004. 
Table 2: Employment in the sugar sector, 2002 (number of workers) ${ }^{a}$

\begin{tabular}{|c|c|c|c|c|c|c|}
\hline & \multicolumn{2}{|c|}{ Brazil } & \multicolumn{2}{|c|}{ North } & \multicolumn{2}{|c|}{ Central/South } \\
\hline & Cane & Sugar & Cane & Sugar & Cane & Sugar \\
\hline \multicolumn{7}{|l|}{ Age group } \\
\hline 10 to 17 years & 1571 & 1035 & 297 & 629 & 1274 & 406 \\
\hline 18 to 29 years & 160488 & 175613 & 36613 & 94075 & 123875 & 81538 \\
\hline 30 to 49 & 169916 & 185080 & 39903 & 90424 & 130013 & 94656 \\
\hline 50 and above & 35645 & 35245 & 9516 & 18050 & 26129 & 17195 \\
\hline Total & 367620 & 396973 & 86329 & 203178 & 281291 & 193795 \\
\hline \multicolumn{7}{|l|}{ Education } \\
\hline Illiterate & 46567 & 70722 & 33722 & 63489 & 12845 & 7233 \\
\hline 8th grade completed & 297810 & 273239 & 50190 & 128320 & 247620 & 144919 \\
\hline High School degree & 20095 & 43238 & 2099 & 9543 & 17996 & 33695 \\
\hline College degree & 3148 & 9774 & 318 & 1826 & 2830 & 7948 \\
\hline
\end{tabular}


Table 3: Ratio of high to low educated workers by sector, 1990-2002 ${ }^{a b}$

\begin{tabular}{lrrrr} 
Sector/Period & 1990-1993 & 1995-1998 & 1999-2002 & Change $^{c}$ \\
\hline Sugar growing & 0.01 & 0.03 & 0.06 & $500 \%$ \\
Sugar processing & 0.07 & 0.12 & 0.56 & $700 \%$ \\
Agriculture other than sugar & 0.04 & 0.05 & 0.08 & $100 \%$ \\
Industry other than sugar & 0.45 & 0.56 & 0.85 & $89 \%$ \\
$\quad$ - Food Industry & 0.89 & 0.97 & 1.2 & $35 \%$ \\
$\quad$ - Beverages & 1.21 & 1.72 & 2.55 & $111 \%$ \\
Services & 1.01 & 1.36 & 1.94 & $92 \%$
\end{tabular}

\footnotetext{
${ }^{a}$ Source: PNAD surveys, 1990-2002. See data appendix for more details.

${ }^{b}$ The ratio is taken as the average number of workers in the sector with 9 or more years of education divided by the number of workers in the sector with less than 5 years of education. Similar patterns are found when using the number of workers below and above the average education level in the survey which is around 7 years.

${ }^{c}$ The change is measured as the percentage change in the rati of high to low educated workers between the 1999-2002 period and the 1990-1993 period.
} 
Table 4: Prices: Stationarity and Engle-Granger test of cointegration ${ }^{a}$

\begin{tabular}{|c|c|c|c|c|}
\hline & \multicolumn{2}{|c|}{ Stationarity } & \multicolumn{2}{|c|}{ Cointegration } \\
\hline & $\begin{array}{r}\text { Levels } \\
\text { ADF }\end{array}$ & $\begin{array}{r}\text { Differences } \\
\text { ADF }\end{array}$ & $\mathrm{ADF}$ & $\mathrm{R}^{2}$ \\
\hline World price & -1.74 & $-4.56^{\star \star \star}$ & & \\
\hline Distrito Federal & -2.17 & 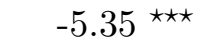 & $-3.64^{\star \star \star}$ & 0.49 \\
\hline Goias & -1.93 & $-5.4^{\star \star \star}$ & $-3.71^{\star \star \star}$ & 0.53 \\
\hline Ceara & -1.76 & $-5.53^{\star \star \star}$ & $-3.93^{\star \star \star}$ & 0.64 \\
\hline Pernambuco & -2.06 & 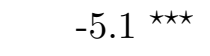 & $-2.81 \star$ & 0.43 \\
\hline Bahia & -2.11 & 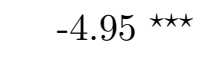 & $-3.5^{\star \star \star \star}$ & 0.47 \\
\hline Minas Gerais & -2.27 & $-5.68^{\star \star \star}$ & $-3.98 \star \star \star \star$ & 0.56 \\
\hline Parana & -2.4 & $-5.75^{\star \star \star}$ & $-4.2^{\star \star \star}$ & 0.56 \\
\hline São Paulo & -2 & $-5.22 \star \star \star$ & $-3.61^{\star \star \star}$ & 0.56 \\
\hline Rio de Janeiro & -2.15 & $-5.19 \star \star \star$ & $-3.66^{\star \star \star}$ & 0.53 \\
\hline Rio Grande do Sul & -2.4 & $-5.03^{\star \star \star}$ & $-4.11^{\star \star \star}$ & 0.52 \\
\hline Para & -2.06 & $-4.5^{\star \star \star}$ & -2.55 & 0.47 \\
\hline
\end{tabular}

${ }^{a} \mathrm{~A} \star \star \star$ implies that the null hypothesis of unit root and/or no cointegration is rejected at the 1 percent significance level; $\star \star$ for rejection at the 5 percent level and $\star$ for rejection at the 10 percent level. The critical values of ADF are -2.58 at 10 percent, -2.89 at 5 percent and -3.49 at 1 percent. Six months lag length is used and all prices are in logs. World price is Contract number 5 of the London Daily Price for refined sugar, f.o.b. Europe, spot. Local prices are consumer prices. 
Table 5: From world to local prices: error-correction model ${ }^{a}$

\begin{tabular}{lrrrrr}
\hline & Trend & $\begin{array}{r}\text { Inmediate } \\
\text { adjustment }\end{array}$ & $\begin{array}{r}\text { Adjustment } \\
\text { to LR eq. }\end{array}$ & \multicolumn{2}{c}{$\begin{array}{c}\text { Speed of } \\
\text { adjustment }\end{array}$} \\
& $(\gamma)$ & $(\delta)$ & $(\theta)$ & 3 months & 1 year \\
\hline Distrito Federal & $0.91^{\star \star \star}$ & $0.25^{\star}$ & $-0.18^{\star \star}$ & $0.55^{\star \star \star}$ & $0.85^{\star \star \star}$ \\
Goias & $1.01^{\star \star \star}$ & $0.26^{\star}$ & $-0.19^{\star \star}$ & $0.61^{\star \star \star}$ & $0.95^{\star \star \star}$ \\
Ceara & $0.92^{\star \star \star}$ & $0.29^{\star \star}$ & $-0.18^{\star \star}$ & $0.58^{\star \star \star}$ & $0.86^{\star \star \star}$ \\
Pernambuco & $0.75^{\star \star \star}$ & 0.11 & $-0.16^{\star \star}$ & $0.37^{\star \star \star}$ & $0.67^{\star \star \star}$ \\
Bahia & $0.75^{\star \star \star}$ & 0.17 & $-0.15^{\star \star}$ & $0.39^{\star \star \star}$ & $0.67^{\star \star \star}$ \\
Minas Gerais & $1.02^{\star \star \star}$ & 0.19 & $-0.20^{\star \star}$ & $0.60^{\star \star \star}$ & $0.96^{\star \star \star}$ \\
Parana & $0.86^{\star \star \star}$ & 0.13 & $-0.19^{\star \star}$ & $0.47^{\star \star \star}$ & $0.80^{\star \star \star}$ \\
São Paulo & $1.00^{\star \star \star}$ & 0.20 & $-0.17^{\star \star}$ & $0.54^{\star \star \star}$ & $0.91^{\star \star \star}$ \\
Rio de Janeiro & $0.94^{\star \star \star}$ & 0.18 & $-0.18^{\star \star}$ & $0.52^{\star \star \star}$ & $0.87^{\star \star \star}$ \\
Rio Grande do Sul & $0.77^{\star \star \star}$ & 0.13 & $-0.20^{\star \star}$ & $0.45^{\star \star \star}$ & $0.73^{\star \star \star}$ \\
Para & $0.87^{\star \star \star}$ & 0.23 & $-0.16^{\star \star}$ & $0.49^{\star \star \star}$ & $0.79 \star \star \star$
\end{tabular}

${ }^{a}$ An error-correction model is run for each State to capture differences in price transmission across regions. A SUR technique is used to correct for common shocks across States. A $\star \star \star$ implies that the null hypothesis that the coefficient is equal to zero is rejected at the 1 percent significance level; $\star \star$ for rejection at the 5 percent level and $\star$ for rejection at the 10 percent level. World price is Contract number 5 of the London Daily Price for refined sugar, f.o.b. Europe, spot. Local prices are consumer prices. 
Table 6: Wage and Employment: Heckman selection model ${ }^{a}$

\begin{tabular}{|c|c|c|c|c|}
\hline & \multicolumn{2}{|c|}{ Wage equation } & \multicolumn{2}{|c|}{ Employment equation } \\
\hline & Coeff. & Std. Error & Coeff. & Std. Error \\
\hline Real price of sugar (log) & -0.016 & 0.034 & $0.217^{\star \star}$ & 0.018 \\
\hline \multicolumn{5}{|l|}{ Interaction with sugar prices $^{b}$} \\
\hline Years of schooling & $0.010 \star \star$ & 0.002 & $-0.015^{\star \star}$ & 0.002 \\
\hline Major sugar producing region & $0.052^{\star \star}$ & 0.016 & $0.052^{\star \star}$ & 0.010 \\
\hline Sugar growing sector & $0.279 \star \star$ & 0.055 & & \\
\hline Sugar processing sector & $0.372^{\star}$ & 0.187 & & \\
\hline Agriculture other than sugar & $0.135^{\star \star}$ & 0.019 & & \\
\hline Industry other than sugar & $0.115^{\star \star}$ & 0.010 & & \\
\hline Employee & -0.040 & 0.026 & & \\
\hline Self-employed & -0.047 & 0.028 & & \\
\hline \multicolumn{5}{|l|}{ Worker characteristics } \\
\hline Age & $0.122^{\star \star}$ & 0.001 & $0.167^{\star \star}$ & 0.000 \\
\hline Age squared & $-0.001 \star \star$ & 0.000 & $-0.002^{\star \star}$ & 0.000 \\
\hline Race (1=white) & 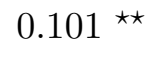 & 0.002 & $-0.069 \star \star$ & 0.003 \\
\hline Gender $(1=$ male $)$ & $0.589^{\star \star}$ & 0.004 & $0.915^{\star \star}$ & 0.002 \\
\hline Urban/rural (1=urban) & $0.153^{\star \star}$ & 0.005 & 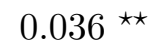 & 0.007 \\
\hline Years of schooling & $0.133^{\star \star}$ & 0.001 & $0.046^{\star \star}$ & 0.001 \\
\hline Number of children ${ }^{c}$ & & & $-0.008 \star \star$ & 0.001 \\
\hline \multicolumn{5}{|l|}{$\underline{\text { Sector dummies }}^{d}$} \\
\hline Sugar growing sector & $0.135^{\star \star}$ & 0.034 & & \\
\hline Sugar processing sector & $0.342^{\star}$ & 0.118 & & \\
\hline Agriculture other than sugar & $-0.170^{\star \star}$ & 0.012 & & \\
\hline Industry other than sugar & $0.119 \star \star \star$ & 0.007 & & \\
\hline \multicolumn{5}{|l|}{ Employment category dummies $^{e}$} \\
\hline Employee & $-0.654^{\star \star}$ & 0.017 & & \\
\hline Self-employed & 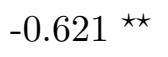 & 0.018 & & \\
\hline State \& Year dummies & Yes & & Yes & \\
\hline Constant & -3.544 & 0.029 & -3.425 & 0.014 \\
\hline
\end{tabular}

Number of Observations $=2106449$

Censored Obervations $=1094867$

Uncensored observations $=1011581$

Wald test of independent equations $(\rho=0)=5898.29$ (rejected)

${ }^{a}$ The Heckman selection model is estimated using maximum likelihood. $\star \star$ stands for signficance at the 1 percent level and $\star$ for significance at the 5 percent level.

${ }^{b}$ Each of the variables is interacted with the log of the real price of sugar.

${ }^{c}$ Measure as the number of children in the household who are 14 years old or younger.

${ }^{d}$ Services is omitted.

${ }^{e}$ The "employer" category is ommitted. 
Table 7: Estimated wage elasticities with respect to local sugar prices ${ }^{a}$

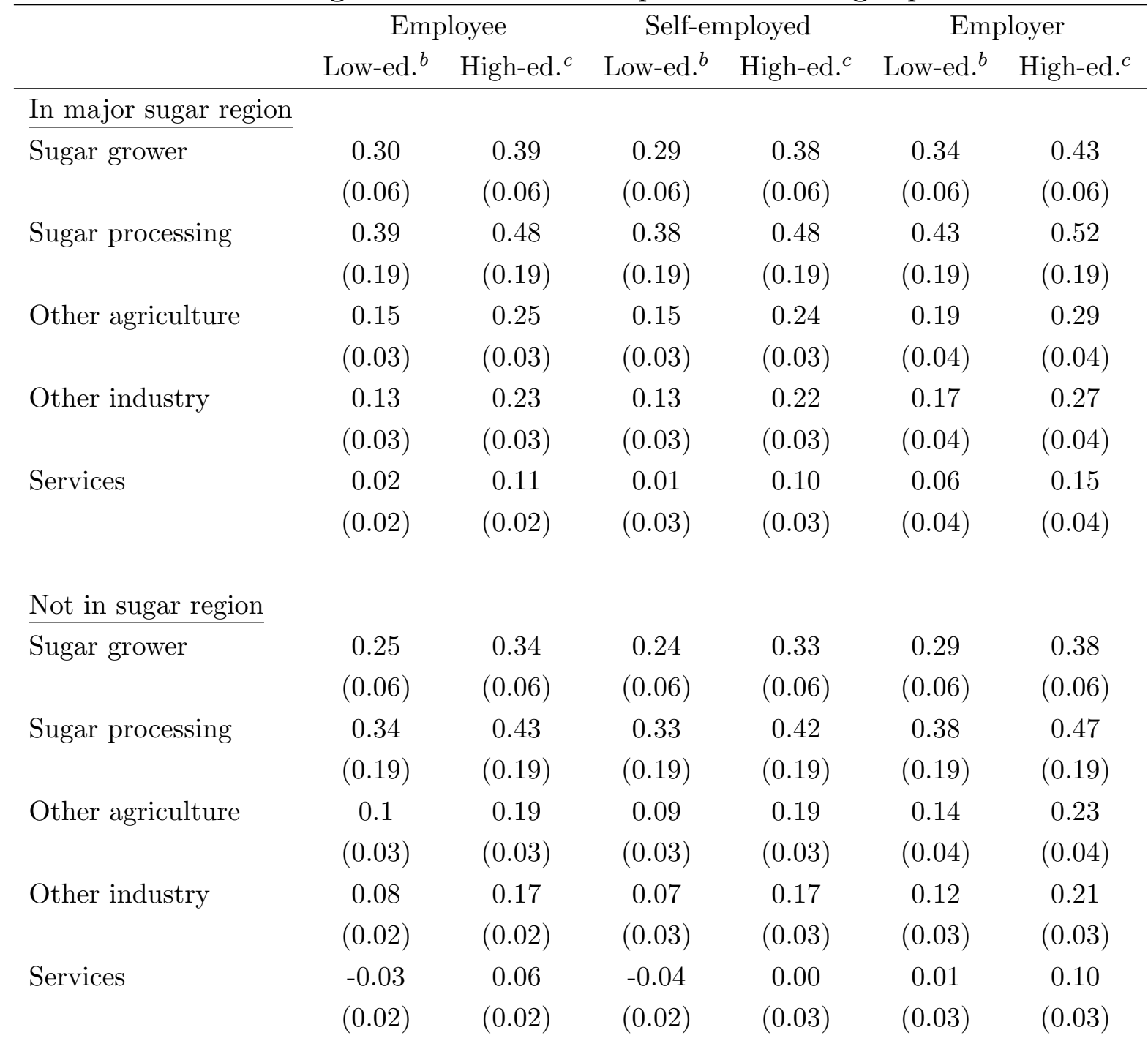

${ }^{a}$ Obtained using the estimates provided in Table 6 and taking averages over group of individuals (using sample weights). Numbers in parenthesis are standard errors. The standard errors were calculated as the square roots of the corresponding variance:

$$
\operatorname{Var}\left(a_{1} \beta_{1}+\ldots+a_{n} \beta_{n}\right)=\sum_{i=1}^{n} a_{i}^{2} \operatorname{Var}\left(\beta_{i}\right)+2 \sum_{i=2}^{n} \sum_{j=1}^{i-1} a_{i} a_{j} \operatorname{Cov}\left(\beta_{i} \beta_{j}\right)
$$

where $\beta_{1} \ldots \beta_{n}$ are the parameter estimates on the interaction variables in the wage equation of the Heckman model and $a_{1} \ldots a_{n}$ are indicators that signal whether a person belongs to a particular group (all $a_{i} \mathrm{~s}$, except years of education, are either zero or one).

${ }^{b}$ Low-educated individuals are definged as those with less than 5 years of education. Elasticities are computed at the average level of education within this group: 2.3 years.

${ }^{c}$ High-educated individuals are defined as those with more than 8 years of education. Elasticities are computed at the average level of education within this group: 11.8 years of education. 
Table 8: Survey data weighted changes in wages by sector and education level after a $10 \%$ change in the world price of sugar, $\%^{a}$

\begin{tabular}{lccc}
\hline & Low-Educated $^{b}$ & Average-Educated $^{c}$ & High-Educated $^{d}$ \\
\hline Sugar growing & 2.05 & 2.73 & 3.41 \\
Sugar processing & 3.06 & 3.54 & 4.39 \\
Other agriculture & 0.56 & 1.12 & 1.95 \\
Other industry & 0.62 & 1.12 & 1.86 \\
Services & -0.46 & 0.08 & 0.82 \\
\hline
\end{tabular}

\footnotetext{
${ }^{a}$ Obtained using the estimates provided in Tables 5 and 6 and taking averages over group of individuals (using sample weights).

${ }^{b}$ Low-educated workers are defined as those with less than 5 years of education.

${ }^{c}$ Average-educated workers are defined as those with more than 4 years of education, but less than 9 .

${ }^{d}$ High-educated workers are defined as those with more than 8 years of education.
} 
Table 9: Changes in household income by income quintiles after a $\mathbf{1 0 \%}$ change in the world price of sugar, $\%^{a}$

\begin{tabular}{lccc}
\hline & Wage Effect $^{b}$ & Employment Effect $^{c}$ & Total $^{d}$ \\
\hline Bottom income quintile & 0.63 & 0.46 & 1.09 \\
Second income quintile & 0.55 & 0.45 & 1.00 \\
Third income quintile & 0.60 & 0.46 & 1.06 \\
Fourth income quintile & 0.68 & 0.43 & 1.11 \\
Top income quintile & 0.71 & 0.28 & 1.00 \\
\hline Total & $\mathbf{0 . 6 7}$ & $\mathbf{0 . 3 5}$ & $\mathbf{1 . 0 4}$
\end{tabular}

${ }^{a}$ Obtained using the estimates provided in Tables 5 and 6 and taking averages over group of individuals (using sample weights).

${ }^{b}$ Measures the average increase in expected household income for those initially employed.

${ }^{c}$ Measures the average increase in expected household income for those initially unemployed.

${ }^{d}$ Measures the unconditional increase in income due to both wages and employment effects. 